\title{
Description of Tabanus yaeyamaensis n. sp. from Yaeyama Islands, Japan (Diptera, Tabanidae)
}

\author{
Hirofumi Hayakawa* and Tsutomu Hasegawa* \\ *Tohoku National Agricultural Experiment Station, \\ Morioka, Iwate 020-01, Japan
}

(Received: April 27, 1981)

\begin{abstract}
Tabanus yaeyamaensis, a new species, was described based on the materials from Ishigaki and Yonakuni Islands, Ryukyu. This species is closely allied to $T$. rufidens (Bigot) in appearance, but can be easily separated from it by having entirely blackish antennae and smoky wings.
\end{abstract}

H. Hayakawa, one of the authors, examined the tabanid specimens preserved at Entomological Laboratory, College of Agriculture, Ehime University by courtesy of Professor T. Ishihara in 1971, and found an unknown species which was collected at Ishigaki and Yonakuni Islands, Ryukyu by $\mathrm{K}$. Hatta and Y. Hori in 1965. T. Hasegawa, one of the authors, also collected the same species as above at Yonakuni Island in 1977. So far, such a kind of species has not been recorded from Yaeyama Islands, Ryukyu (Takahasi, 1977). This species is quite similar to T. rufidens (Bigot) in its general morphological features, but differs in the coloration of antennae and wings. The male and immature stages are still unknown.

\section{Tabanus yaeyamaensis n. sp.}

Female (Figs. 1-3): Length 16-19 mm.

Medium-size, robust, dark olive-yellow to reddish brown species. Antennae entirely blackish. Frons very narrow with long linear middle callus on it. Subcallus pollinose. Wings conspicuously smoky. Legs blackish. Abdomen reddish brown, blackish posteriorly, with conspicuous yellowish grey median triangle and yellowish posterior band on each tergite.

* 早川博文, 長谷川勉: 農林水産省東北農業試験場 （T 020-01 岩手県盛岡市下㕑川字赤平 4)
Head as broad as thorax. Eyes greenish brown with 1 narrow band in relaxed specimens, almost black in dried ones, not covered with piles. Ocellar tubercle absent. Frons very narrow, about 6-7 times as high as basal width, with parallel sides or nearly so, brownish to pale yellow pollinose with short black hairs. Vertex somewhat depressed, covered with black hairs. Basal callus shiny black, narrow triangular, not touching eye-margins. Middle callus shiny black, linear, long, and attached to basal callus. Subcallus light brownish to yellowish pollinose. Face and cheeks greyish yellow pollinose, covered with long pale yellowish hairs, sparsely mixed with short black hairs at upper cheeks.

Antennae rather slender, shorter than the length of head. Scape reddish dark brown to black with bristle-like hairs, as long as broad, half the length of basal segment of flagellum, widened apically. Pedicel small, cup-like, concolorous with scape, covered with short black hairs. Basal segment of flagellum reddish dark brown to black, compressed, narrower than scape, as long as 1.5 times the width, tapering toward apex with a distinct triangular dorsal tooth, with some black short hairs at dorsal tooth. Stylus almost blackish, rather long, as long as the basal segment of flagellum, composed of 4 annulations. Maxillary palpi reddish dark brown, a little shorter than proboscis; first palpal segment short, covered with long 


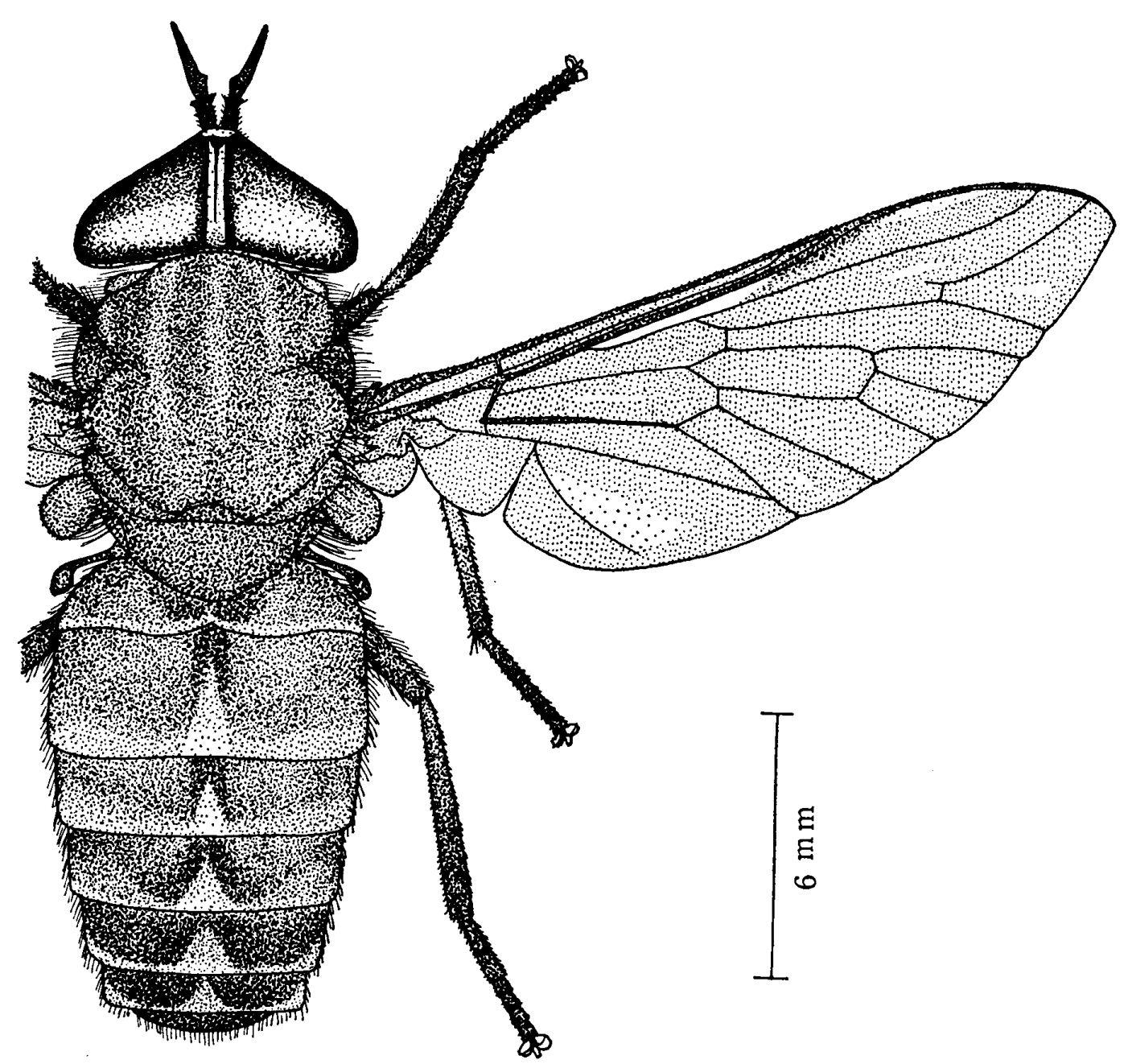

Fig. 1 Tabanus yaeyamaensis n. sp. (female)

black hairs, mixed with pale yellowish hairs basally; second palpal segment slender, sharply tapering toward apex, about 4 times as long as subbasal width, covered with short black hairs. Proboscis reddish dark brown, stout, about $2 / 3$ the length of head.

Thorax slighlty longer than broad. Scutum and scutellum dark olive yellow, covered with short golden hairs and black hairs. Three longitudinal stripes on scutum paler, rather clear. Humeral calli greyish brown with black hairs. Notopleural lobes dark olive yellow with long black hairs. Some tufts of pale yellowish hairs on supraalar and postalar calli. Pleura, sternum and fore coxae greyish brown with pale yellowish hairs.

Wings slightly shorter than body length, conspicuously smoky except some hyaline parts of subcostal cell and 1st radial cell. Pterostigma not clear, reddish dark brown.
Veins dark brown; vein $R_{4}$ with rather long appendix. Halters reddish dark brown, but the knobs light yellowish.

Legs: Femora greyish brown to black; fore femora covered with long black hairs, but mid and hind femora mixed with long golden hairs. Tibiae reddish brown to dark brown; fore tibiae rather blackish apically, covered with black hairs. Tarsi almost black, covered with short black hairs.

Abdomen elongate-oval in shape, reddish brown, blackish mesally and posteriorly. Median triangle on each tergite conspicuous, yellowish grey. Posterior band on each tergite yellowish to reddish brown, slightly widen laterally. Black hairs on most parts of tergites, but golden hairs on paler area of median triangles and posterior bands. Venter reddish brown with paler posterior marginal band on each tergite, covered with short black hairs except paler bands, which cov- 


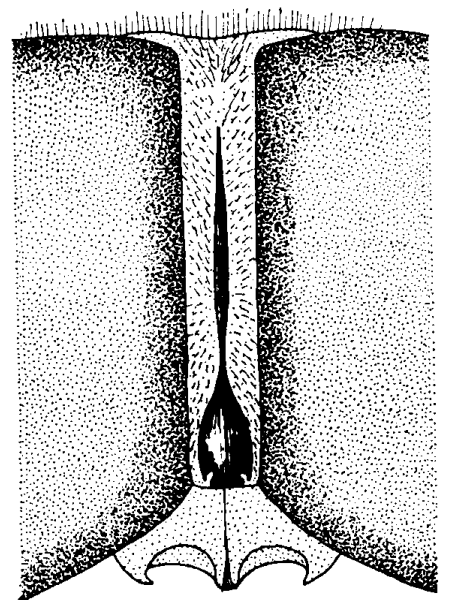

a

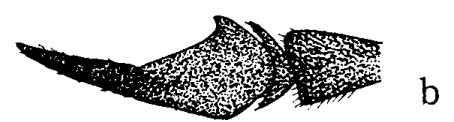

Fig. 2 Tabanus yaeyamaensis n. sp. (female) a: frons, b: antenna, c: palpus.

ered with golden hairs.

Genitalia: Ninth tergite separated, rather large. Tenth tergite small. Cerci roughly round, not distinctly pointed at apex. Eight sternite polygonal, as long as broad, pointed laterally; black flacks clear, narrowly separated at center; hind margin with distinct incision. Genital fork much longer than broad, almost parallel sided. Spermatheca swollen at apex, distinctly black-pigmented.

Male: Unknown.

Type series: Holotype; $\&$ Higashi-zaki, Yonakuni Island, Ryukyu, 5 July 1977, T. Hasegawa leg. Paratypes; $2 \% q$, Hirakubo, Ishigaki Island, Ryukyu, 21 June 1965, Y. Hori leg. 1 o , Mt. Urabe-dake, Yonakuni Island, Ryukyu, 6 July 1965, K. Hatta leg. $1 \%$, the same place as above, 8 July 1965 , Y. Hori leg. 3 우, Higashi-zaki, Yonakuni Island, Ryukyu, 5 July 1977, T. Hasegawa leg. $2 \%$, Higawa, Yonakuni Island, Ryukyu, 5 July 1977, T. Hasegawa leg. Holotype and 2 paratypes are preserved at Division of Entomology, National Institute of Agricultural Sciences in Tsukuba, Ibaraki-ken. Other paratypes are also preserved at Entomological Laboratory, College of Agriculture, Ehime University, Matsuyama-shi, Ehimeken and at Division of Environment, Tohoku

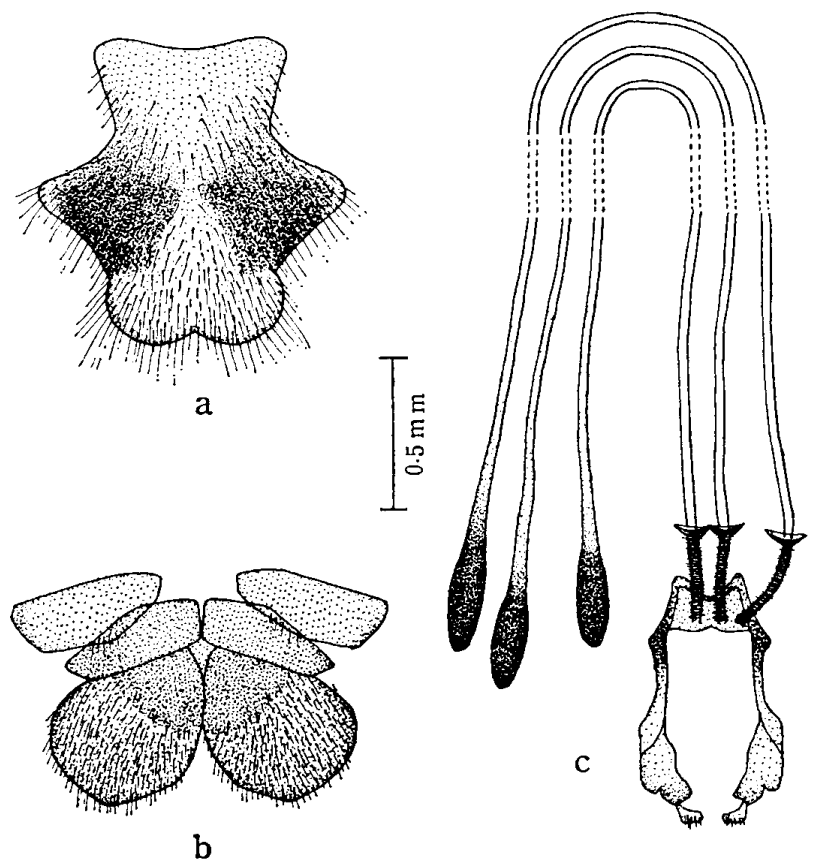

Fig. 3 Tabanus yaeyamaensis n. sp. (female) a: eighth sternite, b: terminal segments, c: genital fork and spermathecal ducts.

National Agricultural Experiment Station, Morioka-shi, Iwate-ken.

Distribution: Yaeyama Islands, Ryukyu. This species is so far recorded from Ishigaki Island and Yonakuni Island, but not from Okinawa Island.

Remarks: The present species is closely related to $T$. rufidens (Bigot) 1887 in its shape and coloration. However, T. yaeyamaensis n. sp. can be easily distinguished from T. rufidens by having entirely blackish antennae and conspicuous smoky wings; in $T$. rufidens the basal portion of flagellum of antennae is generally reddish brown or sometimes blackish only at apical part, and the wings are not so smoky as in $T$. yaeyamaensis. T. rufidens is distributed in Kyushu, Shikoku, Honshu and Hokkaido, its southernmost distribution being at Yakushima Island (Murdoch and Takahasi, 1969; Takahasi, 1977). Therefore, the distribution of both species does not overlap.

The present species was collected from cattle when blood-sucking. It may cause serious nuisances to pasturing livestock in this region.

\section{Acknowledgements}

The authors express their deep gratitude to Pro- 
fessor T. Ishihara, Entomological Laboratory, College of Agriculture, Ehime University for his generosity of providing the specimens. Many thanks are also due to Professor M. Otsuru, Faculty of Medicine, University of Ryukyus and to Dr. $\mathbf{H}$. Takahasi, Tokyo for their kind advice and valuable suggestions.

\section{REFERENCES}

Murdoch, W. P. and H. Takahasi (1969): The female Tabanidae of Japan, Korea and Manchuria. Mem. Entomol. Soc. Wash., 6: 230 pp.

Takahasi, H. (1977): Horseflies Tabanidae. Animals of medical importance in the Nansei Is- lands in Japan, pp. 201-210, Shinjuku Shobo, Tokyo.

\section{摘 要}

アブの 1 新種 Tabanus yaeyamaensis ヤエヤマヤマトアブの記載

八重山諸島の石垣島と与那国島で採集された雌成虫 標本に基づいて, 新種 Tabanus yaeyamaensis ヤエ ヤマヤマトアブを記載した，本種は形態ならびに腹部 背面の斑紋が $T$. rufidens ヤマトアブに酷似している が，触角が全体的に黒色を呈していること，趐が著し くくすんでいることにより，後種とは容易に区別でき る.両種の分布地域は重ならない。 